\title{
II: National Attitudes and Policies toward the Amer- ICAN INDIAN
}

The Corporation and the Indian. Tribal Sovereignty and Industrial Civilization in Indian Territory, 1865-1907, by H. Craig Miner. Columbia: University of Missouri Press, 1976. pp. xv, 236. \$11.00.

John Collier's Crusade for Indian Reform, 1920-1954, by Kenneth R. Philp. Tucson: University of Arizona Press, 1977. pp. xvi, 304. Illustrations, notes and index. $\$ 12.50$.

Historical scholarship involving Native Americans is at last moving beyond the well-worn paths of Plains Indians vs. cavalry and the removal of southeastern people to Oklahoma. The works under review offer convincing portraits of social, economic, and bureaucratic maneuvering in a relatively modern setting. The results are no less devastating.

Both of these young authors have written widely in their fields and have established solid reputations for integrity and thoroughness. Kenneth Philp, associate professor of history at the University of Texas-Arlington, began his study of John Collier as a Ph.D. dissertation at Michigan State University. H. Craig Miner, a Colorado Ph.D. and now associate professor of history at Wichita State University, moved beyond an earlier work on western railroad development to study corporate exploitation on the southern Plains.

Of the two books Miner's is more narrowly focused in locale but still reflects national attitudes and policies. He is primarily concerned with Oklahoma Indian Territory between the Civil War and statehood. Here numerous corporations set out to exploit coal, timber, oil, and the land itself. Pressure created by these economic interests had an even more devastating effect than the lost resources-the erosion of tribal sovereignty. A development pattern was quickly established: "intertribal conflicts, avoidance of Indian law by whites, inadequate enforcement machinery, unwillingness by the federal government to take a definite stand, limited access to markets, all leading to organization, simplification, and exploitation by the corporation." (p. 143).

The corporations were aided, sometimes unwillingly or unknowingly, by two allies-the federal government and Indian people themselves. Because of the tribes' trustee relationship with Washington, entrepreneurs could ignore Indian sovereignty and lobby effectively in Congress and with federal agencies. In addition, all the tribes were divided according to their effectiveness in protecting the land and its resources. They were fragmented into conservatives desirous of excluding the corporations, and so-called "progressives" who sought to join the new wave of economic development.

Outside economic influence began with a series of post-Civil War treaties that granted railroad rights-of-way in eastern Oklahoma. Development of railroads opened the door to further intrusion. They needed both coal and timber for efficient operation and, in turn, encouraged the development of 
cattle grazing lands and oil reserves. Railroad towns brought additional white settlement and greatly accelerated the spread of disease. Federal agencies often moved into these communities, thus separating themselves from the seats of tribal authority.

Taking an "intertribal and intercorporate approach," Miner argues convincingly that both the corporation and the federal government were interested in more than resource exploitation. Native-run firms could have carried that out successfully. Instead, policy was clearly intended to destroy tribal sovereignty. By 1882, for example, Congress established a precedent that it could grant privileges to corporations on Indian land without consulting the tribe. Miner concluded that "a thing more damaging to the national hopes of the Indians could hardly be imagined." (p. 101)

Professor Miner found it especially discouraging to observe that those individuals economically most interested in destroying Indian sovereignty were the same men determining policy in Washington. But that action was not incongruous with widespread public acceptance of the "prerogative of progress." Within the spirit of social Darwinism the Indian, it was argued, "must take his chance with others in the economic struggle that would measure the fitness of his race by the profits it generated." (p. 80)

This well-documented study relies primarily upon tribal records, especially Cherokee, Choctaw, and Osage and federal documents. Corporate opinions and actions were thus developed indirectly. At times the narrative travels through some extremely detailed sections, but the author's style makes it understandable. There is a need for more maps centrally focused on the particular regions discussed.

This reviewer has no serious criticism of the writing style, documentation, or general thrust of the narrative. But I am concerned with the exclusive high level of national significance Miner places on his subject. He states that "at no time were the parameters of tribal sovereignty more thoroughly tested than in the late nineteenth century, and in no way more than by the challenge to Indian governments and to the U.S. government posed by the desire of corporations to gain privileges upon tribal lands from whatever power was competent to give them." (p. xiv)

Without trying to de-emphasize the importance of corporate and governmental exploitation in Oklahoma, I challenge his view that tribal authority was never more thoroughly tested. Surely the Menominee battle in Wisconsin concerning their termination in the 1950 s and eventual restoration in the 1970s equals the struggle outlined in Miner's work. This is a point strongly felt but one that does not detract from an excellent piece of historical scholarship.

As noted in the foreword to John Collier's Crusade for Indian Reform by historian Francis P. Prucha, few people were as influential as John Collier, Commission of Indian Affairs, 1933-1945, in changing the direction of American Indian policy. This small, stoop-shouldered man aroused deep and lasting commitments from supporters and equally strong antagonism from critics. 
Seeking to formulate a new set of values to replace the precepts of social Darwinism, Collier, early in life, was convinced that the "rise of capitalism had caused anarchic individualism, wasteful competition, and an unhealthy obsession with materialism." (p. xiii) But as outlined by Kenneth Philp, Collier faced a dilemma common to many middle class settlement workers. As a social worker, Collier found it extremely difficult to apply an idealistic view of a classless society to the chaotic reality faced by urban immigrants, or reservation Indians. In both environments Collier discovered it was easiser for an elite to provide direction than to listen to individual aspirations. For example, as B.I.A. commissioner, he used social scientists to draw up tribal constitutions and corporate charters, compelling Indians to accept white ideals rather than seeking native viewpoints.

Philp places great significance on Collier's visit to Taos, New Mexico, during November-December, 1920, as the touchstone for his entire adult life. Here the reformer observed the Pueblo holding "secrets desperately needed by the white world." Their society possessed "a mystical social significance" that offered an example of community life that had eluded Collier while a social worker in New York City. (p. 2)

For the next several decades, through a wide variety of public and private organizations, Collier opposed any policy degrading Indian cultures that should be preserved. He argued that federal officials could not save or usefully assimilate the red man by crushing his soul. Simply put, Collier wanted to develop and conserve Indian life through government-sponsored, self-help activities on the part of native people. More specifically the Georgia native fought to protect Pueblo lands, to end restrictions on Indian dances, to support the right to use peyote by the Native American Church, to encourage solving rural problems (instead of forcing Indians into urban centers), and to limit missionary influence over native education.

Collier's most powerful influence came as the creative force behind the "Indian New Deal" of the 1930s. Here he sought to parallel efforts to conserve tribal land and to provide public relief with an assault on the previously established land allotment system. Collier believed that the policy, emanating from the 1887 Dawes Act, deprived Indians of "vast quantities of property and created a class of landless paupers who depended upon the federal government."' (p. 127)

Although the commissioner's ideas and policy statements found support among closely knit tribes who used the Indian Reorganization Act (1934) to promote social and economic progress, they also met relentless criticism. His romantic notions faced opposition from missionaries, congressmen, bureau personnel, and Indians who favored assimilation. According to Philp, Collier "overestimated his capacity to reconstruct Indian affairs and introduced too many ideas which often created confusion." He failed to convince Congress that "the preservation of native heritage, with its cooperative insitutions, would enhance the Indian's ability to cope with modern life." (p. 211)

In the only full-length account of John Collier and the Indians, Professor 
Philp has presented a first-rate study. The text is thoroughly documented and pleasantly interspersed with excellent photographs. He writes well, has a full command of the materials, and places Collier's career within a broader historical perspective.

Students of Indian-white relations in a modern setting will appreciate the efforts of both of these scholars.

\section{_David A. Walker University of Northern Iowa}

American Indian Policy in Crisis: Christian Reformers and the Indian. 18651900, by Francis Paul Prucha. Norman: University of Oklahoma Press, 1976. pp. 456. Bibliography, illustrations, index. $\$ 15.00$.

"When the whiteman landed on American shores he immediately fell upon his knees to praise God, then he fell upon the Indian." The accuracy of this often-repeated observation is of course open to considerable debate, but the recurrent acts of white-initiated violence against Native Americans are so well documented that the nation still suffers from a collective guilt complex. The seemingly endless cases of martial conflict between Indians and whites have received such thorough attention that relatively little more needs to be written about them. But such is not the case with the more subtle features of forced acculturation and detribalization which bordered on an unwritten policy of cultural genocide. In the long run these attacks upon tribal life and sovereignty have proven more destructive of Indian rights than all of the cumulative wars and broken treaties during four centuries of contact.

Francis Paul Prucha, professor of history at Marquette University, broadens our understanding of the post-Civil War era by analyzing the various white reform groups and their efforts to solve the "Indian Problem." Prucha quickly alerts the reader that this is not a study of comparative cultures or Indian viewpoints, but rather an analysis of white attitudes and actions. Though reformers frequently disagreed on procedures, almost all shared the ethnocentric view that Indians "were to be individualized and Americanized, becoming in the end patriotic American citizens indistinguishable from their white neighbors." (p. v) This myopic and self-righteous view, even though tempered with honesty and the best of intentions, proved calamitous for Indians whose own observations were rarely solicited.

American Indian Policy in Crisis adopts a chronological framework involving detailed treatment of President Grant's Peace Policy, rivalry between War and Interior departments for control of Indian affairs, rise of the Board of Indian Commissioners, changing programs in Indian education, and the growing debate over Indian citizenship. Most enlightening, however, is the author's discussion of the various reform groups and their leaders. From Herbert Welsh's nationally recognized Indian Rights Association to the more regional Boston Indian Citizenship Committee, these groups worked toward 
Copyright of Annals of Iowa is the property of State of Iowa, by \& through the State Historical Society of Iowa and its content may not be copied or emailed to multiple sites or posted to a listserv without the copyright holder's express written permission. However, users may print, download, or email articles for individual use. 